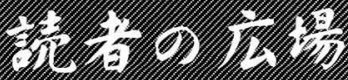

\section{長岡半太郎の分光学 一理研でなされた先駆的核構造研究一}

この一文を私の贖罪のために書くことを打許しいただき たいと思います．そして，幾人かの共感をいただければ大 変うれしく思います。な扔，この内容の一部は物理学会第 52 回年会物理学史分科会で報告いたしました1).

私が共同研究者の一人であった若杉昌德君と本誌の「総 説と解説」に「超微細構造による原子核分光」を執筆した のは，3 年前になります2)。そのときも，ここで話題にす るW. Pauli の論文 ${ }^{3)}$ を参考文献として取り上げをした。 ほかにも，幾度か，私はこの古典的論文を引用してきすし た．その度ごとに実は，私は内心忸怩たる思いをしていた のです．なぜなら，この論文を手にとって自分で読んでぬ たことがなかったからです。それがドイツ語であること と， 70年も前の論文ですから，そのときの私の仕事に直 接役に立つ訳がないことは自明なので, 誰か読むかもしれ ない参考文献として揭げるだけで，自責の念をごまかして いました。

今からちょうど一年程前に, Pauli の論文を手にする機 会がありました１0年以上も前から私の懸案であった， 原子核が陽子・中性子で構成されていないとして原子核の 場を記述する手だてをいよいよ考えようと思い立って，ま ずPauli の論文を読むことにしたのです．私の懸案という のは, 超微細構造異常（文献 2 参照）に関するものです. しかし私の期待はまったくかなえられず（数式が一つもな い!），代わりに思いもかけなかった事実を発見しなした。 長岡半太郎と彼の協力者が, 原子核構造とのかかわりを考 えながら, 同位体シフトと超微細構造に関する先駆的研究 をしていたことです。これには驚き屯した，しかもここの 有名なP Pauli の論文は長岡らの論文に刺激されて書いたも のであることを，Pauli 自身が論文の中で明らかにしてい ます，彼は長岡らの論文を非常に高く評価しています。

あの土星模型の長岡半太郎が，原子核の構造を明らかに しようと, 原子スペクトル分光実験を執拗に続けていたと は夢にも思わなかった，まったくの驚きでした，長岡とい えば「土星模型」と，いまだにそればかりが喧伝されてい ます、私は, 歴史的意義は別として, 長岡の土星模型も, これとよく比較されるJ. J. Thomson の原子模型も, 物理 的には意味があると評価したことはありませんが，この度 は両者の原論文を読んでみました（両者の論文が，仲良 く, Phil. Mag. Vol. 7 (1904) に揭載されていたことはう れしい驚きでした）読んでみて，私はどちらがよりいい 模型であるなどとはいいえないことがわかりました，両者 いずれも，当時の原子スペクトルを説明することを主たる
目的にしています. 幾つかの電子が等間隔で一つの軌道上 に並んでいるところは, 両者同じであり, Thomson は一 様電荷分布の中に殼構造的に電子軌道があるとしているの に対して, 長岡は一様電荷分布の外側にそのような電子軌

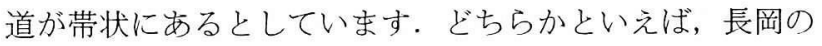
模型の方がわかり易かったといえるでしょう。をれれから， 長岡が自ら論文の序論で述べているように, 彼の模型は

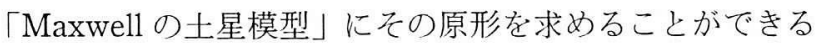
ことからも理解され易かったように考えられます。

彼らの一様電荷分布のところを，原子核がつくる場と読 み替えると，両者はほとんど一致することになります，長 岡らの Hg 原子スペクトルに関する同位体効果の論文を読 むと文，長岡が扔ぼろげながら原子核のつくる場という考 えに到達していたことがわかります。ここのところが慧眼 の土Pauli の目に止まり，彼に非常に大きな影響を与える 結果になったのです．Pauli はこれを次のように巧みにそ して簡潔にあとめて扔ります3).

... wollen wir hier den Gedanken Nagaoka und seiner Mitarbeiter versuchsweise in der allgemeinen Fassung aufnehmen, daß die Satelliten in dem zusammengesetzten Bau des Kernes und den davon herrührenden Abweichungen des Kernkraftfeldes vom Coulombschen Feld ihre Entstehungsursache haben. Wir wollen überdies voraussetzen, daß der Kern ein nicht verschwindendes resultierendes Impulsmoment besitzt.

後半の Wir 以下は，この論文を不朽のものとした原子核 スピンの概念をはじめて述べたところです，そしてこれが 磁気的超微細相互作用の始まりであります.

土星模型のほんとうの意味は, 長岡がそこに巨大な core を考えたことによって「原子スペクトルをと抢して 原子核が見える」に違いないと執拁に分光実験を続けてい たことにある，といまでは考えていすす，もしも長岡が， 最初から正しく，原子核の大きさは原子のそれの 1 万分 の1岁るいはそれ以下であると考えたならば，「原子スペ クトルをと抢して原子核が見える」とは思いもつかなかっ たでしょう. 事実, Rutherfordのグループからは誰一人 として超微細構造・同位体シフトに手を出していません， 彼の原子模型が真実とは違っていたとしても，それによっ て得られた先見性沙優れて物理的であったと思います。長 岡らの研究が当時いかに先見性に優れていたものかは, Pauli がその論文の終りに次のようにまとめていることを 知れば十分でしょう3).

「私がこの論文を書いた目的は，長岡らのような分光実 験に理論物学者の注意を喚起するためである。これらの実 験が系統的になされるならば，純粋に光学的な手段だけで 原子核構造のかなりのことを明らかにできるであうう.」

このように優れた長岡らの研究がその後日本ではまった く発展がみられなかったことは, 物理学の蓄積という観点 
からすれば，後学のわれわれには大変残念であります。も ちろん, 幾つかの関連論文がその後わが国からも出ていま す.しかし，いずれも長岡らの先駆的研究を積極的に支持 する論文ではありません. 引用すらしないことが多いので す. むしろ外国の研究者が1930年代になっても, 長岡ら の研究をその後の日本人研究者の仕事よりも高く評価して いたことを指摘して抒きたいと思います。私の主観的印象 でないことを示すために，原論文の該当部をそのまま引用 したいのですが，頁数に制限がありますので，私が簡潔に 抄訳しながら説明することにします。

まず，長岡らの論文が発表されてすぐに， Ruarkら （米）は長岡らが一般的に原子スペクトルには同位体効果 があることを示したことを指摘し，実験データとしても当 時他の追随を許さないのものであったことを明快に述べて います5). ところが，1931年に発表された日本の K. Murakawaの表現はこれと正反対でありました6)。彼は， 長岡らの論文はオバケを見ていたので（nicht frei von Geistern ist）とるにたりないといい，彼らを支持する Ruarkの議論もしたがって意味がないといいきっています. これだけを読むと「ああそうか，10年も前の測定だから な」と思ってしまいますが，これに対して翌年，ドイツか ら手厳しく批判する論文が発表されています7)。 それによ ると，とるにたりないのは Murakawa の論文であって， 彼の測定は間違っている.われわれが測定した結果は長岡 らの測定結果によく合っている，と結論しています。この 著者の一人 H. Schüler は, 当時ドイツを代表する分光学 者の一人であります。彼は1934年に同位体シフト測定か ら Sm 同位元素で質量数150 と 152 の間で急激な核半径の 変化が起っているという注目すべき発見をしています（文 献 2 参照).

これらの例から推測されるように, 超微細構造 · 同位体 シフトによる長岡らの先駆的核構造研究は1930年代から 急激に発展を遂げなす。1950年代に至り, 今日の原子核 物理学に抢いて最も基本的な模型である殼模型（文献 2 参照）が出現するまでの 20 年間, 長岡らの先駆的研究が あったにもかかわらず，日本からの寄与はまったく無きに 等しいことは嘆かわしい限りであります。長岡の土星模型 をかついでばかりいる間に，日本は長岡が始めた物理学 （原子核分光学）の発展に寄与することができなかったの です。土星模型をかつぎまわることは，長岡のひいきの引 き倒しなっています。

Herzberg の教科書にはP Pauli の話は出てきなすが（文 献 2 参照), Nagaoka の論文は出てきません．私にとって
は，これが Nagaokaについて知り得なかった（あるいは 知ろうとしなかった）遠因であります，Landolt-Börnsteinなど，いわゆる権威ある reference books には，超 微細構造・同位体シフトの実験に関しては1930年代以降 の文献しか揭載されてい屯せん：これらの研究は1930年 代から本格的に始まりますので, 通常の意味ではそれで十 分です.が, 誰が pioneer であったかとなると, これだけ ではきわめて不十分であることを，この度の経験から学び ましたそそして「歷史は作られてしまう」ことを実感しま した。

超微細構造 ·同位体シフトによる原子核構造研究の先駆 者として, H. Nagaoka は N. Bohr, W. Pauli とともに永 久に記憶されるべきであります。しかも，彼は実験を行な っていたことに注目すべきであります。したがって，長岡 らの論文は4)超微細構造・同位体シフトによる原子核構造 研究実験の世界最初の論文です，私は，本誌に「総説と解 説」を執筆したとき2), Nagaokaの名をPauli と並べて掲 げることができなかったことを大変悔いております。

物理学会講演概要1)を送ってしまってからしばらくし て, 島津備愛先生から「長岡半太郎伝」8)のあることをご 指摘いただきました，そこには八木汇里氏による「長岡の 分光学研究と核構造論 $(1908 \sim 24) 」$ 一章があり, 八木 氏は長岡半太郎が原子核構造を明らかにしようとする意図 を持っていたことを科学史家として指摘しています．25 年も前にこのことを指摘して抢られた八木氏に敬意を表す るとともに，それが研究現場にはなったく伝わっていなか ったことを残念に思います。あらためて歴史とは何かを問 うた次第であります。

理化学研究所. サイクロトロン研究室 稲村 卓

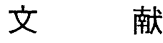

1）稲村 卓：物理学会第 52 回年会, 3 月 $28 \sim 31$ 日, 名古屋.

2) 稲村 卓: 若杉昌徳 : 分光研究 43,61 (1994).

3) W. Pauli: Naturwiss. 12, 741 (1924).

4) H. Nagaoka, Y. Sugiura, and T. Mishima: Japanese Journ. of Physics 2, 121 (1923); Nature 113, 459 (1924); and H. Nagaoka and Y. Sugiura: Japanese Journ. of Physics 2, 167 (1923).

5) A. E. Ruark and R. L. Chenault: Phil. Mag. S6, 50, 937 (1925); A. E. Ruark: ibid, S7, 1, 977 (1926).

6) K. Murakawa: Z. Phys. 73, 366 (1931).

7) H. Schüler und E. G. Jones: Z. Phys. 74, 631 (1932).

8）長岡半太郎伝（藤岡由夫監修, 板倉 · 木村 · 八木共著, 朝日 新聞社刊 (1973)). 